\title{
Correction to: Erythrocyte concentrations of chromium, copper, manganese, molybdenum, selenium and zinc in subjects with different physical training levels
}

\author{
M. Maynar ${ }^{1}$, F. J. Grijota², J. Siquier-Coll' ${ }^{1}$ I. Bartolome ${ }^{1}$, M. C. Robles ${ }^{1}$ and D. Muñoz ${ }^{1 *}$
}

Correction to: J Int Soc Sports Nutr 17, 35 (2020)

https://doi.org/10.1186/s12970-020-00367-4

The original article [1] contains an incorrect affiliation for co-author, F. J. Grijota.

The correct affiliation can be viewed in this correction article (Faculty of Language and Education, Antonio de Nebrija University, Madrid, Spain).

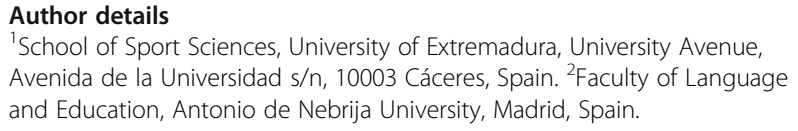

Published online: 14 April 2021

\section{Reference}

1. Muñoz D, et al. Erythrocyte concentrations of chromium, copper,

manganese, molybdenum, selenium and zinc in subjects with different physical training levels. J Int Soc Sports Nutrn. 2020;17:35 https://doi.org/1 0.1186/s12970-020-00367-4.

The original article can be found online at https://doi.org/10.1186/s12970020-00367-4.

*Correspondence: diegomun@unex.es

${ }^{1}$ School of Sport Sciences, University of Extremadura, University Avenue, Avenida de la Universidad s/n, 10003 Cáceres, Spain

Full list of author information is available at the end of the article

(c) The Author(s). 2021 Open Access This article is licensed under a Creative Commons Attribution 4.0 International License, which permits use, sharing, adaptation, distribution and reproduction in any medium or format, as long as you give appropriate credit to the original author(s) and the source, provide a link to the Creative Commons licence, and indicate if changes were made. The images or other third party material in this article are included in the article's Creative Commons licence, unless indicated otherwise in a credit line to the material. If material is not included in the article's Creative Commons licence and your intended use is not permitted by statutory regulation or exceeds the permitted use, you will need to obtain permission directly from the copyright holder. To view a copy of this licence, visit http://creativecommons.org/licenses/by/4.0/ The Creative Commons Public Domain Dedication waiver (http://creativecommons.org/publicdomain/zero/1.0/) applies to the data made available in this article, unless otherwise stated in a credit line to the data. 